\title{
DIFFERENT MECHANISMS OF ACTION OF HISTAMINE IN ISOLATED ARTERIES OF THE DOG
}

\author{
MAKOTO KONISHI*, NOBORU TODA \& MASAKATSU YAMAMOTO* \\ Department of Pharmacology, Shiga University of Medical Sciences, Seta, Ohtsu 520-21, and *Department of Surgery, \\ Kansai Medical University, Moriguchi, Osaka 570, Japan
}

1 In helically-cut strips of dog coronary, superior mesenteric, right gastro-epiploic and renal arteries contracted with prostaglandin $\mathrm{F}_{2 \alpha}\left(\mathrm{PGF}_{2 \alpha}\right)$, histamine produced a dose-related relaxation, while, in contrast, the amine caused only a contraction of cerebral arterial strips.

2 The contractile response of cerebral arteries to histamine was attenuated by chlorpheniramine $\left(10^{-6} \mathrm{M}\right)$ but was unaffected by cimetidine $\left(10^{-5} \mathrm{M}\right)$. Relaxant responses to histamine of coronary and renal arteries were significantly attenuated by treatment with cimetidine and to a similar extent by combined treatment with cimetidine and chlorpheniramine. Chlorpheniramine alone was ineffective.

3 In mesenteric and gastro-epiploic arteries, relaxant responses to histamine were attenuated only slightly by cimetidine. Chlorpheniramine slowed the development of histamine-induced relaxations but did not alter the magnitude of the relaxations. Combined treatment with these $\mathrm{H}_{1}$ - and $\mathrm{H}_{2}$ antagonists attenuated the histamine-induced relaxations to an appreciably greater extent than treatment with cimetidine alone.

4 It may be concluded that the cerebroarterial contraction induced by histamine is mediated through $\mathrm{H}_{1}$-receptors and the relaxations of coronary and renal arteries induced by histamine are mediated through $\mathrm{H}_{2}$-receptors. It appears that $\mathrm{H}_{1}$ - and $\mathrm{H}_{2}$-receptors interact with each other to produce potentiation of histamine-induced relaxations of mesenteric and gastro-epiploic arteries.

\section{Introduction}

Two types of receptors $H_{1}$ (Ash \& Schild, 1966) and $\mathrm{H}_{2}$ (Black, Duncan, Durant, Ganellin \& Parsons, 1972) participate in vascular responses to histamine. Over the past few years, influences of histamine on cat and rat gastric (Guth \& Smith, 1978a; Harvey, Owen \& Shaw, 1980), rat, rabbit, cat and dog mesenteric (Flynn \& Owen, 1975; Angus \& Korner, 1977; Pawlik, Tague, Tepperman, Millar \& Jacobson, 1977; Guth \& Smith, 1978b), rabbit and pig coronary (Coruzzi, Bongrani \& Bertaccini, 1979; Hagen \& Paegelow, 1980), rabbit renal (Angus \& Korner, 1977), rabbit ear (Ercan \& Türker, 1975), cat and dog cerebral vasculatures (Edvinsson \& Owman, 1975; Toda, 1977; Wahl \& Kuschinsky, 1979) and cat and dog blood pressure (Black, Owen \& Parsons, 1975) have been described. Some of these authors have postulated from the results of experiments in situ that both $\mathrm{H}_{1}$ - and $\mathrm{H}_{2}$-receptors participate in a common response, such as a vasodilatation, an increase in the blood flow and a fall of the blood pressure (Black et al., 1975; Flynn \& Owen, 1975; Angus \& Korner, 1977; Pawlik et al., 1977; Guth \& Smith, 1978a, b; Harvey et al., 1980). However, there is little in vitro information concerning the mechanism of action of histamine.
The present study was undertaken to analyse the effect of histamine on different arteries of the dog, including cerebral, gastro-epiploic, mesenteric, coronary and renal, by the use of an $\mathrm{H}_{1}$-antagonist, chlorpheniramine, and $\mathrm{H}_{2}$-antagonist, cimetidine, and to compare the mechanism of action of histamine.

\section{Methods}

Mongrel dogs of either sex, weighing 8 to $15 \mathrm{~kg}$, were anaesthetized with intraperitoneal injections of sodium pentobarbitone in a dose of $50 \mathrm{mg} / \mathrm{kg}$ and were killed by bleeding from the common carotid arteries. The brain, heart, kidney, superior mesenteric artery and right gastroepiploic artery were rapidly removed. Basilar and middle cerebral arteries (0.6-0.8 mm o.d.) were isolated from the brain, interventricular branches of the coronary artery $(0.9-1.1 \mathrm{~mm})$ were isolated from the heart, intrarenal interlobar branches of the renal artery $(0.6-0.8 \mathrm{~mm})$ were isolated from the kidney. Distal portions of superior mesenteric $(0.7-0.9 \mathrm{~mm})$ and right gastro-epiploic arteries $(0.5-0.7 \mathrm{~mm})$ were also 
isolated. The arteries were cut helically into strips, approx. $20 \mathrm{~mm}$ long. Each strip was fixed vertically between hooks, under an optimal resting tension of $1.5 \mathrm{~g}$ (Toda, Hatano \& Hayashi, 1978), in a muscle bath containing the nutrient solution, which was maintained at $37 \pm 0.5^{\circ} \mathrm{C}$ and aerated with a mixture of $95 \% \mathrm{O}_{2}$ and $5 \% \mathrm{CO}_{2}$. The hook anchoring the upper end of the strips was connected to the lever of a force-displacement transducer (Sanei Sokki Co., Tokyo, Japan). The composition of the nutrient solution was $(\mathrm{mM}): \mathrm{Na}^{+} 162.1, \mathrm{~K}^{+} 5.4, \mathrm{Ca}^{2+} 2.2$, $\mathrm{Mg}^{2+}$ 1.0, $\mathrm{Cl}^{-}$159.0, $\mathrm{HCO}_{3}{ }^{-} 14.9$ and dextrose 5.6. The $\mathrm{pH}$ of the solution was 7.2 to 7.3. Before the start of experiments, all preparations were allowed to equilibrate for 90 to $120 \mathrm{~min}$ in the control media, during which time the fluids were replaced every 15 to $20 \mathrm{~min}$.

Isometric contractions and relaxations were recorded on an ink-writing oscillograph (Sanei Sokki Co., Tokyo, Japan). The contractile response to $\mathrm{K}^{+}$ ( $30 \mathrm{~mm})$ was first obtained. Histamine was added directly to the bathing media in cumulative concentrations, and the contractions relative to those induced by $\mathrm{K}^{+}(30 \mathrm{mM})$ were recorded. Arterial strips were contracted with prostaglandin $F_{2 \alpha}\left(P G_{2 \alpha}\right)$ when the relaxant effect of histamine was obtained; contractions induced by $\mathrm{PGF}_{2 \alpha}$ were between 15 and $30 \%$ of the size of contractions induced by $\mathrm{K}^{+}$
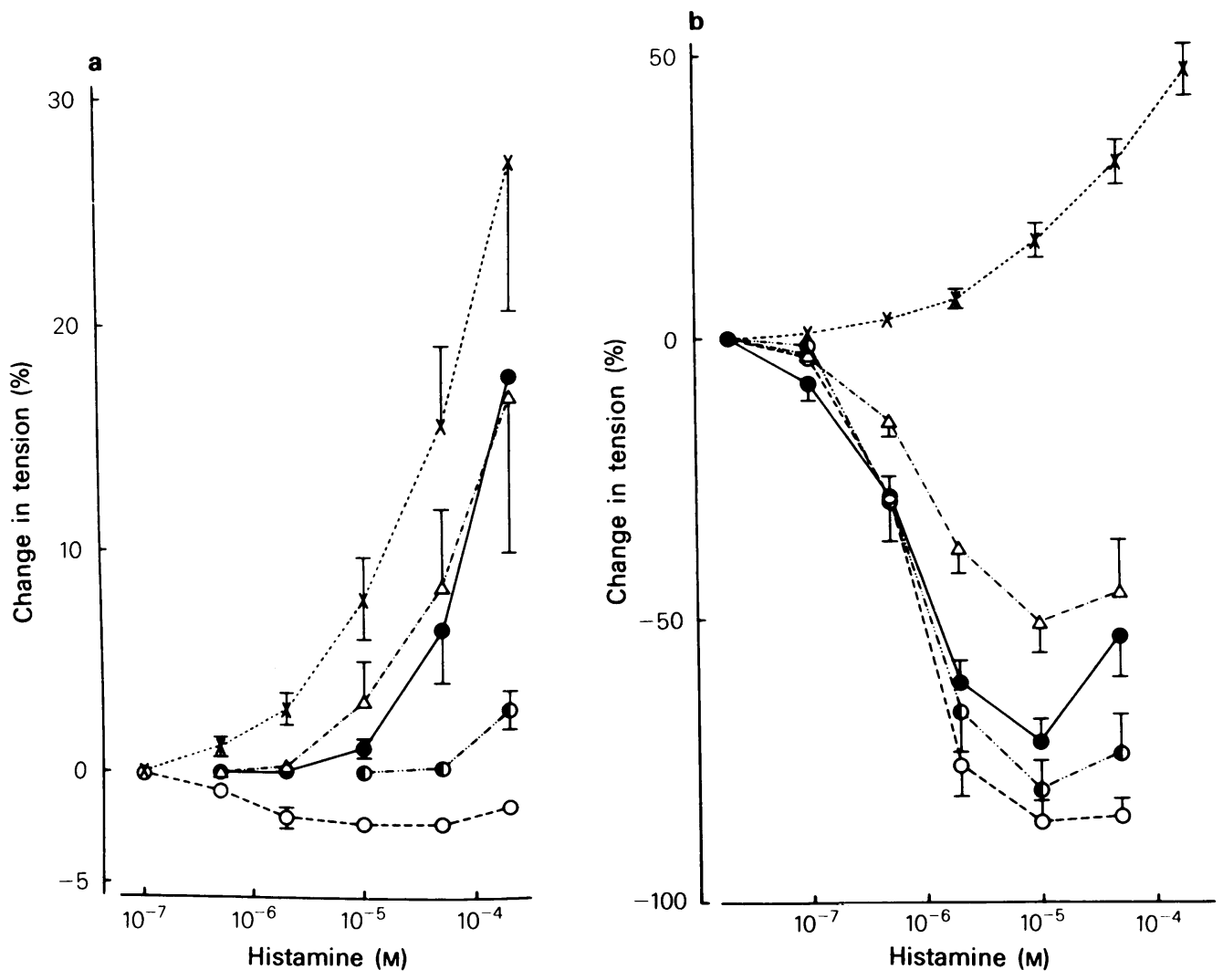

Figure 1 Dose-response curves for histamine in cerebral $(\times)$, mesenteric $(\Theta)$, gastro-epiploic $(\Delta)$, renal $(\Theta)$, and coronary $(\mathrm{O})$ arteries isolated from dogs under resting conditions (a) and when contracted with prostaglandin $\mathrm{F}_{2 \alpha}$ $\left(\mathrm{PGF}_{2 \alpha}\right)(\mathrm{b})$. In (a), contractions induced by $\mathrm{K}^{+}(30 \mathrm{~mm})$ were taken as $100 \%$; mean absolute values in cerebral, mesenteric, gastro-epiploic, renal and coronary arteries were $2253 \pm 470 \mathrm{mg}(n=8), 2257 \pm 208 \mathrm{mg}(n=7)$, $2059 \pm 322 \mathrm{mg}(n=5), 1696 \pm 416 \mathrm{mg}(n=5)$ and $2820 \pm 483 \mathrm{mg}(n=3)$, respectively. In (b), maximum relaxations induced by papaverine $\left(10^{-4} \mathrm{M}\right)$ were taken as $100 \%$; mean absolute values in gastro-epiploic, mesenteric, renal and coronary arteries were $423 \pm 39 \mathrm{mg}(n=15), 418 \pm 80 \mathrm{mg}(n=15), 647 \pm 107 \mathrm{mg}(n=12)$ and $611 \pm 107 \mathrm{mg}$ $(n=10)$, respectively. The mean value of contractions induced by $\mathrm{K}^{+}(30 \mathrm{~mm})$ (taken as $\left.100 \%\right)$ in cerebral arteries was $1664 \pm 589 \mathrm{mg}(n=5)$. Absolute contractions induced by $\mathrm{PGF}_{2 \alpha}$ in gastro-epiploic, mesenteric, renal, coronary and cerebral arteries averaged $383 \pm 44 \mathrm{mg}(n=15), 398 \pm 73 \mathrm{mg}(n=15), 543 \pm 106 \mathrm{mg}(n=12), 417 \pm 57 \mathrm{mg}$ $(n=10)$ and $222 \pm 39 \mathrm{mg}(n=5)$, respectively. The magnitude of the rapid phase of relaxations was measured. Vertical bars represent s.e.mean. 
$(30 \mathrm{~mm})$. At the end of each series of experiments, papaverine $\left(10^{-4} \mathrm{M}\right)$ was added to attain the maximum relaxation (Toda, 1974). Relaxations induced by histamine relative to papaverine-induced relaxations were recorded. Dose-response curves for histamine were reproducible after a second series of experiments in the preparations used; therefore, the second dose-response curve was taken as a control for experiments with blocking agents. Preparations had been exposed for 20 to 30 min to blocking agents, before dose-response curves for histamine were obtained. In some mesenteric and coronary arterial strips contracted with $\mathrm{PGF}_{2 \alpha}$, the response to a single concentration $\left(10^{-6} \mathrm{M}\right)$ of histamine was obtained, and the time from the addition of histamine to the half maximum relaxation induced by histamine was compared before and after the blocking agents. Results shown in the text and figures represent the mean values \pm s.e.mean. Statistical analyses were made using Student's $t$ test. Drugs used were histamine dihydrochloride, prostaglandin $F_{2 \alpha}$ (Ono Co., Osaka, Japan), chlorpheniramine maleate, cimetidine, phentolamine mesylate, $( \pm)$ propranolol hydrochloride, atropine sulphate, aminophylline, phenylephrine hydrochloride and adenosine.

\section{Results}

\section{Responses to histamine of different arteries}

Under resting conditions when there was no or only a slight active tone, helical strips of cerebral, mesenteric and gastro-epiploic arteries contracted in response to histamine $\left(2 \times 10^{-6}\right.$ to $\left.2 \times 10^{-4} \mathrm{M}\right)$ in a dose-dependent manner (Figure 1a). Cerebroarterial contractions were significantly greater in concentrations of $2 \times 10^{-6}$ and $10^{-5} \mathrm{M}$ histamine $(P<0.01)$ than those of mesenteric arteries. Renal arteries contracted only slightly. Coronary arterial strips responded with a slight relaxation.

In the strips of gastro-epiploic, mesenteric, renal and coronary arteries contracted with $\mathrm{PGF}_{2 \alpha}\left(10^{-7}\right.$ to $\left.2 \times 10^{-6} \mathrm{M}\right)$, the addition of histamine in concentrations ranging from $10^{-7}$ to $10^{-5} \mathrm{M}$ caused a doserelated relaxation (Figure $1 \mathrm{~b}$ ). The maximum relaxation of gastro-epiploic arteries induced by histamine $\left(10^{-5} \mathrm{M}\right)$ relative to that induced by papaverine $\left(10^{-4} \mathrm{M}\right)$ was significantly less than the relaxations of the other arteries $(P<0.01)$. Mean values of the median effective concentration $\left(E D_{50}\right)$ in gastroepiploic, mesenteric, renal and coronary arteries were $10.4,7.6,9.3$ and $8.2 \times 10^{-7} \mathrm{M}$, respectively. Similar relaxations were induced by histamine in mesenteric arterial strips contracted with phenylephrine, but the relaxations seen in $\mathrm{K}^{+}$
(10 to $15 \mathrm{mM}$ )-contracted arteries were less than those in the preparations contracted with $\mathrm{PGF}_{2 \alpha}$ or phenylephrine. In contrast, cerebral arteries contracted with $\mathrm{PGF}_{2 \alpha}$ did not respond to histamine $\left(2 \times 10^{-6}\right.$ to $\left.2 \times 10^{-4} \mathrm{M}\right)$ with a relaxation but with a contraction (Figure 1b). In $\mathrm{PGF}_{2 \alpha}$-contracted arteries, contractions induced by histamine were greater than those seen under resting conditions. Similar potentiation of the contractile response to angiotensin II or 5-hydroxytryptamine (5-HT) is obtained in partially-contracted arteries (Toda, unpublished data), suggesting that the contractile response depends upon the extent of active tone of the arteries.

\section{Modification by histamine antagonists}

Treatment with chlorpheniramine $\left(10^{-6} \mathrm{M}\right)$ did not significantly influence the magnitude of relaxation of mesenteric arterial strips induced by histamine (Figure $2 \mathrm{a}$ ), but slowed the development of relaxations. On the other hand, the relaxant response was attenuated by cimetidine $\left(10^{-5} \mathrm{M}\right)$ (Figure $2 \mathrm{~b}$ ). Further increase in concentration of cimetidine to $3 \times 10^{-5}$ and $10^{-4} \mathrm{M}$ did not produce any additional attenuation of the response; therefore, a concentration of $10^{-5} \mathrm{M}$ was used in the remainder of the experiments. Combined treatment with chlorpheniramine and cimetidine attenuated the histamine-induced relaxations to an appreciably greater extent than treatment with cimetidine alone (Figure 2c). The ratio of $E D_{50}$ values in the presence and absence of the combined treatment was $21.1 \pm 6.2$, while the ratio with cimetidine alone was $5.4 \pm 3.2$. The magnitude of relaxations of right gastro-epiploic arteries induced by histamine was also unaffected by treatment with chlorpheniramine $\left(10^{-6} \mathrm{M}\right)$ (Figure $\left.3 \mathrm{a}\right)$; however, development of relaxation was slowed as it was in mesenteric arteries. Cimetidine $\left(10^{-5} \mathrm{M}\right)$ attenuated the relaxation (Figure $3 \mathrm{~b}$ ). The dose-response curve for histamine was shifted further to the right following combined treatment with chlorpheniramine and cimetidine (Figure $3 \mathrm{c}$ ). The ratios of $\mathrm{ED}_{50}$ values in the presence and absence of cimetidine alone and cimetidine plus chlorpheniramine were $5.6 \pm 2.5$ and $11.2 \pm 2.4$, respectively. Relaxant responses to histamine of mesenteric $(n=4)$ and gastro-epiploic arteries $(n=3)$ were not influenced by treatment with phentolamine $\left(10^{-6} \mathrm{M}\right)$, propranolol $\left(10^{-6} \mathrm{M}\right)$, aminophylline $\left(2 \times 10^{-5} \mathrm{M}\right)$ or atropine $\left(10^{-7} \mathrm{M}\right)$.

In mesenteric arterial strips, modifications by histamine antagonists of the time course of relaxations induced by a single concentration of histamine $\left(10^{-6} \mathrm{M}\right)$ were studied. Following histamine, rapid relaxations developed initially, from which partial recovery took place; then relaxations slowly developed and levelled off 40 to 50 min later. Chlorpheniramine $\left(10^{-6} \mathrm{M}\right)$ abolished the rapid relaxation; 

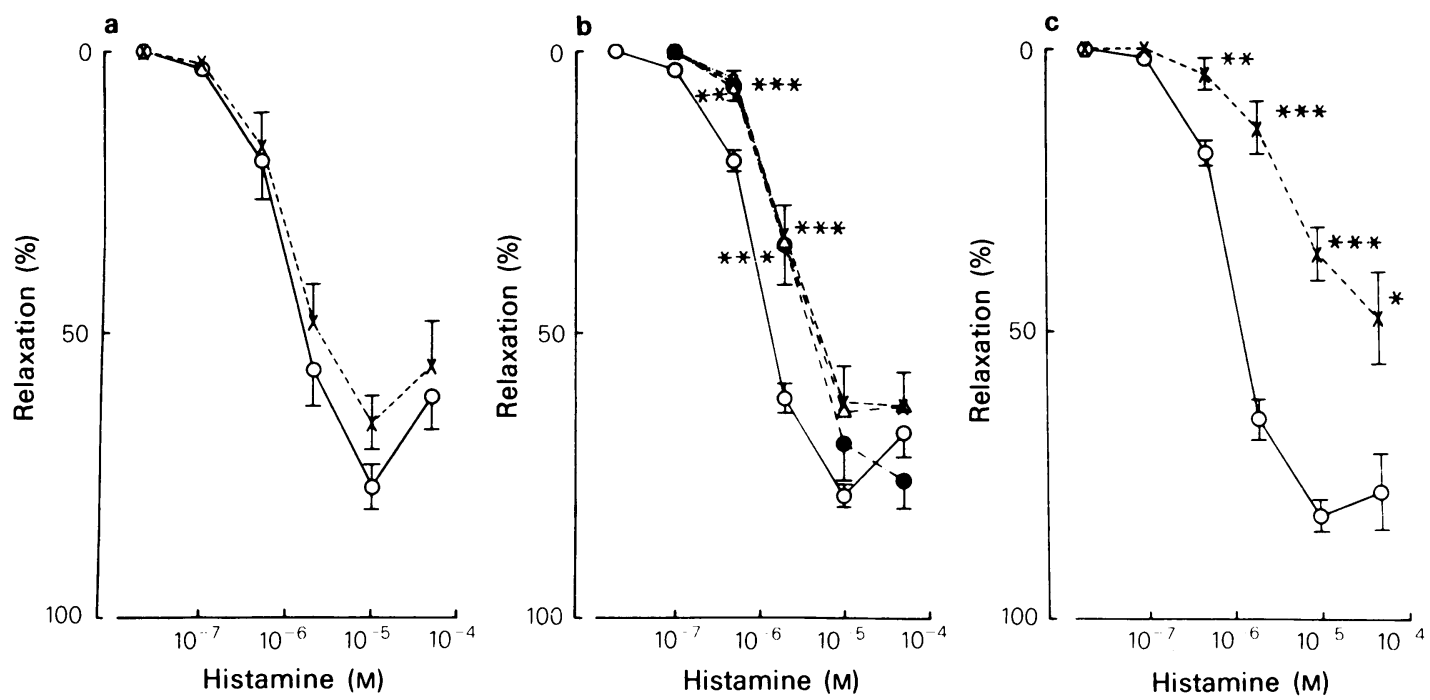

Figure 2 Modification by chlorpheniramine, cimetidine and chlorpheniramine plus cimetidine of the relaxant response of mesenteric arterial strips to histamine. The strips were contracted with prostaglandin $F_{2 \alpha}\left(P G F_{2 \alpha}\right)$. Maximum relaxations induced by papaverine $\left(10^{-4} \mathrm{M}\right)$ were taken as $100 \%$; mean absolute values in control $(O)$ and chlorpheniramine $\left(10^{-6} \mathrm{M}\right)$-treated $(\times)$ preparations were $563 \pm 98 \mathrm{mg}(n=10)$ and $685 \pm 78 \mathrm{mg}(n=10)$, respectively in (a); the values in control $(O)$ and cimetidine $\left(10^{-5}(\times), 3 \times 10^{-5}(\triangle)\right.$ and $\left.10^{-4} \mathrm{M}(\bullet)\right)$-treated strips were $675 \pm 68 \mathrm{mg}(n=28), 591 \pm 78 \mathrm{mg}(n=9), 703 \pm 132 \mathrm{mg}(n=10)$ and $493 \pm 63 \mathrm{mg}(n=9)$, respectively in (b); the values in control $(O)$ strips and those treated with chlorpheniramine $\left(10^{-6} \mathrm{M}\right)$ plus cimetidine $\left(10^{-5} \mathrm{M}\right)(\times)$ were $503 \pm 107 \mathrm{mg}(n=6)$ and $490 \pm 95 \mathrm{mg}(n=6)$, respectively in (c).

Significantly different from control: ${ }^{* * *} P<0.001 ;{ }^{* *} P<0.01 ;{ }^{*} P<0.02$.
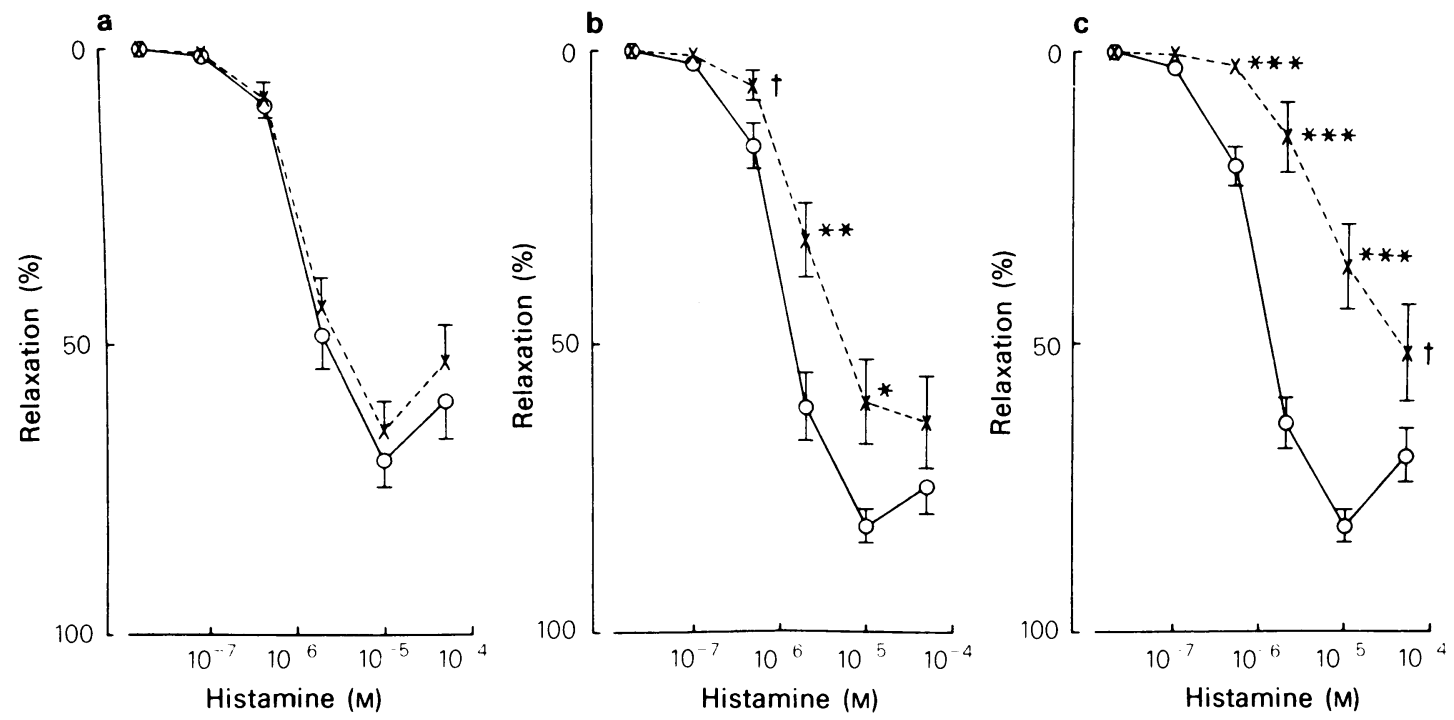

Figure 3 Modification by chlorpheniramine, cimetidine and chlorpheniramine plus cimetidine of the relaxant response of gastroepiploic arterial strips to histamine. The strips were contracted with prostaglandin $F_{2 \alpha}\left(P F_{2 \alpha}\right)$. Maximum relaxations induced by papaverine $\left(10^{-4} \mathrm{M}\right)$ were taken as $100 \%$; mean absolute values in control $(O)$ and chlorpheniramine $\left(10^{-6} \mathrm{M}\right)$-treated $(\times)$ strips were $548 \pm 75 \mathrm{mg}(n=12)$ and $670 \pm 99 \mathrm{mg}(n=12)$, respectively in (a); the values in control $(O)$ and cimetidine $\left(10^{-5} \mathrm{M}\right)$-treated $(\times)$ strips were $766 \pm 164 \mathrm{mg}(n=8)$ and $924 \pm 154 \mathrm{mg}(n=8)$, respectively in (b); the values in control $(O)$ strips and those treated with chlorpheniramine $\left(10^{-6} \mathrm{M}\right)$ plus cimetidine $\left(10^{-5} \mathrm{M}\right)(\times)$ were $505 \pm 101 \mathrm{mg}(n=6)$ and $733 \pm 141 \mathrm{mg}(n=6)$, respectively in $(\mathrm{c})$. Significantly different from control; ${ }^{* *} P<0.001 ;{ }^{* *} P<0.01 ;{ }^{*} P<0.02 ; \dagger P<0.05$. 
the magnitude of the slow relaxation was not altered (Figure 4). In control preparations, the magnitude of the rapid and slow relaxations averaged $62.1 \pm 5.3 \%$ and $46.2 \pm 6.1 \% \quad(n=10)$, respectively, of the papaverine $\left(10^{-4} \mathrm{M}\right)$-induced relaxations. Following treatment with chlorpheniramine, the magnitude of the slow relaxation averaged $54.6 \pm 5.8 \%$. Mean values of the time required to induce $50 \%$ of the maximum relaxation in the absence and presence of the $\mathrm{H}_{1}$-antagonist were $73 \pm 6 \mathrm{~s}(n=10)$ and $413 \pm 94 \mathrm{~s}$ $(n=10)$, respectively. When the slow relaxations stabilized in the presence of chlorpheniramine, contractions were induced by the addition of cimetidine, which however did not alter the arterial tension in control media. Treatment with cimetidine $\left(10^{-5} \mathrm{M}\right)$ did not appreciably alter the time course of the histamine-induced relaxation. In control strips, the magnitude of the rapid and slow relaxations averaged $60.7 \pm 7.2 \%$ and $39.2 \pm 6.1 \%(n=6)$, respectively, while those in preparations treated with cimetidine averaged $56.2 \pm 8.7 \%$ and $34.3 \pm 8.0 \%(n=6)$, respectively. Mean values of the time required to induce $50 \%$ maximum relaxation before and after treatment with the $\mathrm{H}_{2}$-antagonist were $79 \pm 12 \mathrm{~s}$ and $83 \pm 12$ s $(n=6)$, respectively.

\section{Control}
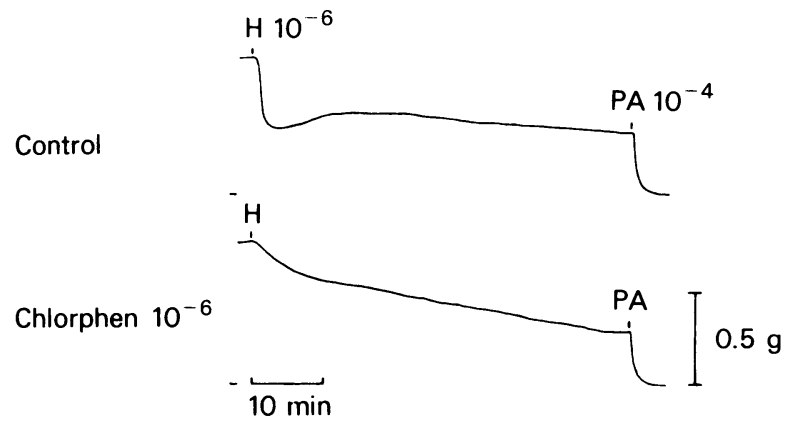

Control

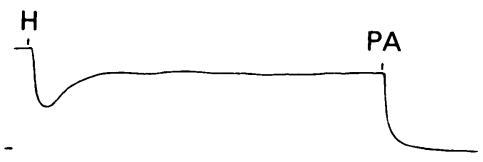

Cimet $10^{-5}$

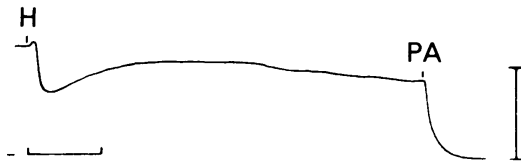

Figure 4 Time course of relaxations induced by a single concentration $\left(10^{-6} \mathrm{M}\right)$ of histamine in two mesenteric arterial strips obtained from the same dog in the absence or presence of chlorpheniramine (Chlorphen) and cimetidine (Cimet). Horizontal lines just left of each tracing represent the level before the addition of prostaglandin $F_{2 \alpha} . H=$ histamine; $P A=10^{-4} \mathrm{M}$ papaverine.
In helical strips of coronary and renal arteries contracted with $\mathrm{PGF}_{2 \alpha}$, relaxant responses to histamine were appreciably attenuated by treatment with cimetidine $\left(10^{-5} \mathrm{M}\right)$ but were not reduced or potentiated by chlorpheniramine $\left(10^{-6} \mathrm{M}\right)$ (Figures 5 and 6). Combined treatment of coronary arteries with chlorpheniramine and cimetidine caused a similar degree of attenuation to that induced by cimetidine alone (Figure 5). Similar results were also obtained in renal arteries $(n=4)$. Coronary arterial strips responded to a single concentration of histamine $\left(10^{-6} \mathrm{M}\right)$ with a different time course of relaxation from that seen in mesenteric arteries (cf. Figures 4 and 7). The histamine-induced relaxation was abolished by cimetidine but was unaffected by chlorpheniramine (Figure 7).

The addition of adenosine in concentrations ranging from $10^{-8}$ to $10^{-4} \mathrm{M}$ relaxed the mesenteric arterial strips dose-dependently; the relaxation was unaffected by treatment with chlorpheniramine $\left(10^{-5} \mathrm{M}\right)$ $(n=4)$ or cimetidine $\left(10^{-4} \mathrm{M}\right)(n=4)$.

The dose-contractile response curve for histamine in cerebral arterial strips was shifted parallel to the

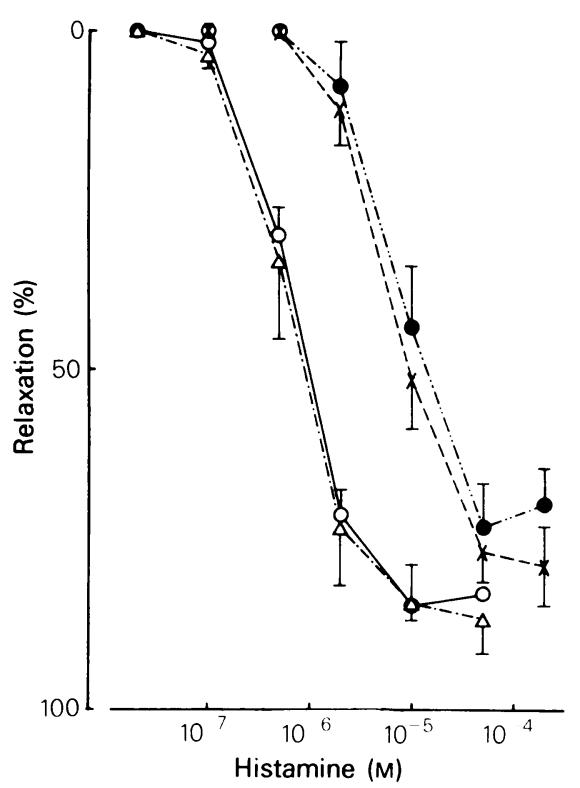

Figure 5 Modification by chlorpheniramine, cimetidine and chlorpheniramine plus cimetidine of the relaxant response of coronary arterial strips to histamine. The strips were contracted with prostaglandin $\mathrm{F}_{2 \alpha}$. Maximum relaxations induced by papaverine $\left(10^{-4} \mathrm{M}\right)$ were taken as $100 \%$; mean absolute values in control strips $(O)$ and those treated with $10^{-6} \mathrm{M}$ chlorpheniramine $(\triangle), 10^{-5} \mathrm{M}$ cimetidine $(\times)$ and chlorpheniramine plus cimetidine $(\odot)$ were $885 \pm 68 \mathrm{mg}$ $(n=27), 934 \pm 101 \mathrm{mg}(n=7), 1069 \pm 93 \mathrm{mg}(n=11)$ and $1022 \pm 110 \mathrm{mg}(n=9)$, respectively. 


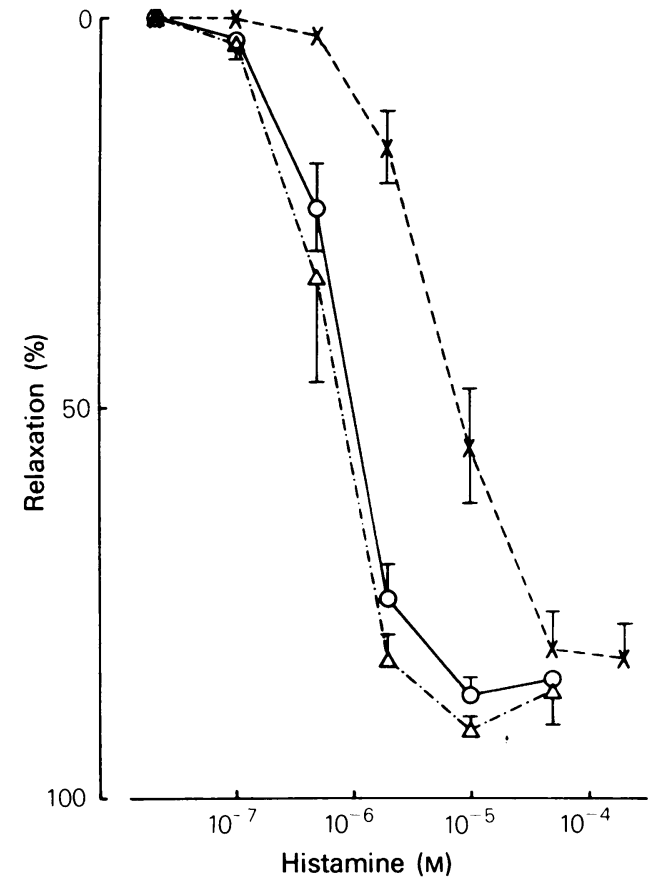

Figure 6 Modification by cimetidine and chlorpheniramine of the relaxant response to histamine of renal arterial strips contracted with prostaglandin $F_{2 \alpha}$. Maximum relaxations induced by papaverine $\left(10^{-4} \mathrm{M}\right)$ were taken as $100 \%$; mean absolute values in control $(O)$, cimetidine $\left(10^{-5} \mathrm{M}\right)$-treated $(\times)$ and chlorpheniramine $\left(10^{-6} \mathrm{M}\right)$-treated $(\triangle)$ strips were $871 \pm 106 \mathrm{mg}(n=17), 1244 \pm 199 \mathrm{mg} \quad(n=11)$ and $842 \pm 113 \mathrm{mg}(n=6)$, respectively.

right by treatment with chlorpheniramine $\left(10^{-6} \mathrm{M}\right)$, the shift being identical to that in preparations treated with both chlorpheniramine and cimetidine (Figure 8). Treatment with cimetidine $\left(10^{-5} \mathrm{M}\right)$ alone failed to alter the histamine-induced contraction.

\section{Discussion}

The present study revealed that the addition of histamine caused a dose-related relaxation of isolated arteries of the dog, including gastro-epiploic, mesenteric, renal and coronary arteries contracted with PGF $_{2 \alpha}$. Histamine-induced vasodilatation has also been demonstrated in vivo in stomach arterioles of cats and rats (Guth \& Smith, 1978a), in perfused stomach vasculature of cats (Harvey et al., 1980), in mesenteric vasculature of anaesthetized dogs (Pawlik et al., 1977) and cats (Guth \& Smith, 1978b) and in hindlimb and carotid vasculature of unanaesthetized rabbits (Angus \& Korner, 1977).

The magnitude of the relaxant responses of right gastro-epiploic and mesenteric arteries to histamine was unaffected by treatment with chlorpheniramine but the development of relaxation was slowed. Treatment with cimetidine attenuated the relaxant response of right gastro-epiploic and mesenteric arteries to histamine. Further attenuation of the response was induced by combined treatment with chlorpheniramine and cimetidine. These findings suggest that the relaxation of gastro-epiploic and mesenteric arteries caused by histamine are mediated partly through $\mathrm{H}_{2}$-receptors and mainly through both $\mathrm{H}_{1}$ - and $\mathrm{H}_{2}$-receptors. It appears that these receptors interact with each other to produce a potentiation of the relaxation. On the other hand, in perfused cat stomach, mesenteric and hindlimb vasculatures, the dose-vasodilator response curve for histamine is displaced to the right by mepyramine and further to the right by mepyramine plus cimetidine or metiamide, but neither of these $\mathrm{H}_{2}$-antagonists alone displaces the histamine dose-response curve (Flynn \& Owen, 1975; Guth \& Smith, 1978b; Harvey et al., 1980). Findings obtained in the present study are consistent with theirs concerning the demonstration of a possible involvement of $\mathrm{H}_{1}$ - and $\mathrm{H}_{2}$-receptor interactions in the histamine-induced arterial relaxation. However, there is a discrepancy in the effectiveness of either the $\mathrm{H}_{1^{-}}$or $\mathrm{H}_{2}$-antagonist, which may derive

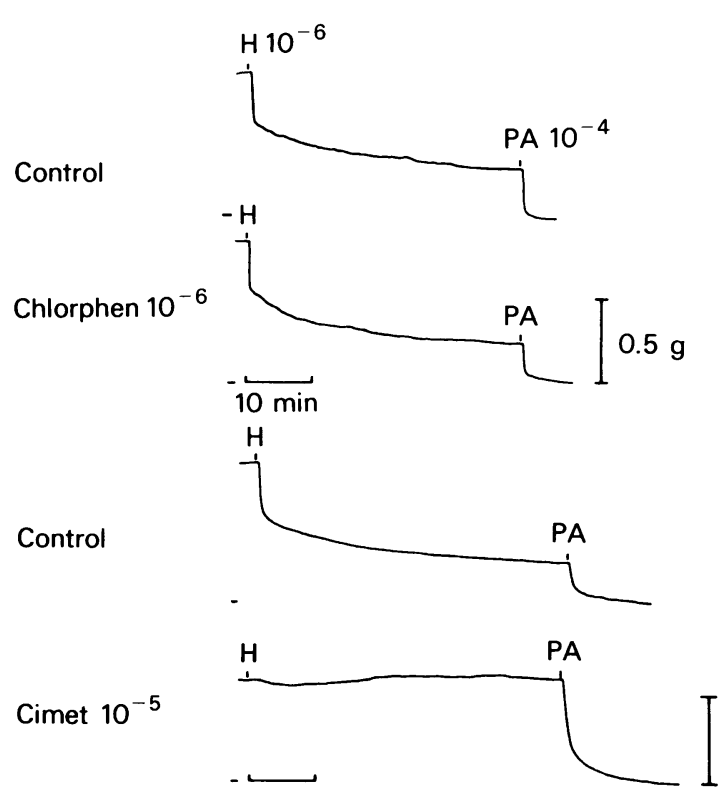

Figure 7 Time course of relaxations induced by a single concentration of $10^{-6} \mathrm{M}$ histamine in two coronary arterial strips obtained from the same dog in the absence or presence of $10^{-6} \mathrm{M}$ chlorpheniramine (Chlorphen) and $10^{-5} \mathrm{M}$ cimetidine (Cimet). Horizontal lines just left of each tracing represent the level before the addition of prostaglandin $\mathrm{F}_{2 \alpha}$. 


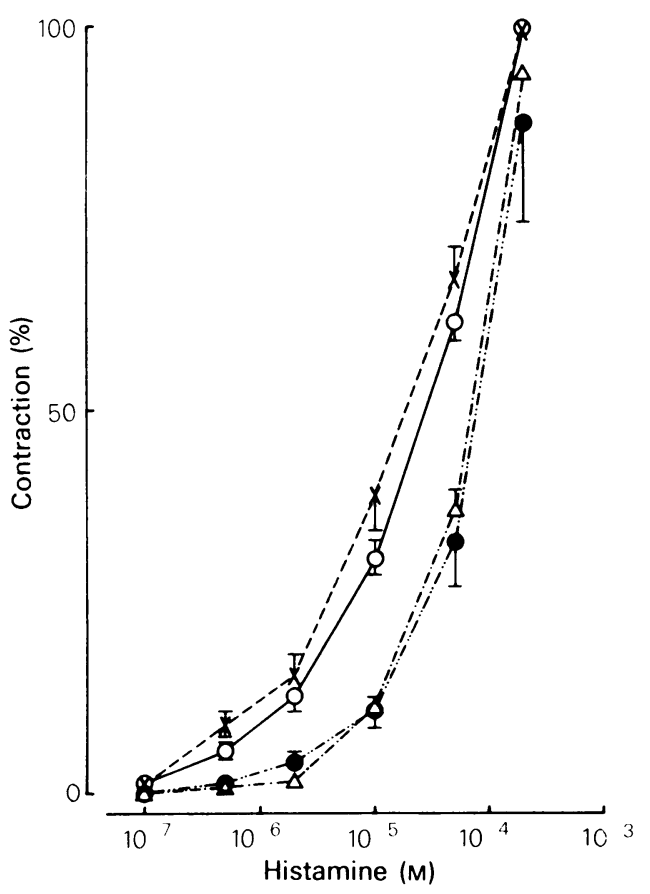

Figure 8 Modification by chlorpheniramine $\left(10^{-6} \mathrm{M}\right.$, $\triangle, n=8)$, cimetidine $\left(10^{-5} \mathrm{M}, \times, n=5\right)$ and chlorpheniramine plus cimetidine $(\bullet, n=8)$ of the contractile response of cerebral arterial strips to histamine under resting conditions; control value $(O, n=13)$. Contractions induced by $2 \times 10^{-4} \mathrm{M}$ histamine in control media were taken as $100 \%$; mean absolute value was $668 \pm 128 \mathrm{mg}(n=13)$.

from different species (dog vs. cat) and different experimental conditions (isolated helical strips vs. perfused vasculature in situ).

Relaxations induced by histamine on gastroepiploic and mesenteric arterial strips were not influenced by phentolamine, propranolol, atropine and aminophylline, suggesting that $\alpha-$ and $\beta$ adrenoceptor, cholinoceptor and adenosine-related mechanisms are not involved. Further, cimetidine and chlorpheniramine in concentrations used in the present study, provide a specific antagonism to histamine-induced relaxations, since relaxations induced by adenosine were not influenced by these antagonists.

In the data demonstrating the time course of relaxations of mesenteric arteries induced by a single concentration of histamine, chlorpheniramine abolished the rapid relaxation; however, the magnitude of slowly-developing relaxations in the arteries treated with chlorpheniramine was not significantly different from that of maximum relaxations in control preparations. Cimetidine did not alter the time course of relaxation. These results may indicate that the rapid relaxation is mediated by $\mathrm{H}_{1}$-receptors. Similar effectiveness of $\mathrm{H}_{1}$-antagonists has been demonstrated in perfused mesenteric vasculatures of anaesthetized dogs (Pawlik et al., 1977), in the gastric vasculature of anaesthetized cats (Harvey et al., 1980) and in the pulmonary vasculature of anaesthetized dogs (Tucker, Weir, Reeves \& Grover, 1975). Further, the pattern of the vasodilator response to 2-methylhistamine, an $\mathrm{H}_{1}$-agonist, resembles the pattern seen with histamine infused after treatment with $\mathrm{H}_{2}$-antagonists (Pawlik et al., 1977).

In helical strips of coronary and renal arteries, relaxant responses to histamine were appreciably attenuated by cimetidine but were not influenced by chlorpheniramine. Combined treatment with chlorpheniramine and cimetidine produced a similar degree of attenuation to that induced by cimetidine alone. Similar results were obtained in cat pial arteries (Wahl \& Kuschinsky, 1979). It may be concluded that as far as the dog coronary and renal arteries used in the present study are concerned, the relaxant responses to histamine are mediated through $\mathrm{H}_{2}$-receptors. It has been reported that in isolated coronary arterial strips of the pig, histamineinduced contractions are potentiated by metiamide (Hagen \& Paegelow, 1980) and a decrease in the coronary perfusion pressure of anaesthetized rabbits is attenuated by metiamide or cimetidine (Coruzzi $\boldsymbol{e t}$ al., 1979). Isolated coronary arteries of the dog responded to a single concentration of histamine $\left(10^{-6} \mathrm{M}\right)$ with only a relaxation as shown in Figure 7, which was abolished by cimetidine. These findings also support the hypothesis that only $\mathrm{H}_{2}$-receptors are involved in the histamine-induced relaxation of coronary arteries.

Histamine did not relax but contracted dog cerebral arteries under resting conditions or when partially contracted with $\mathrm{PGF}_{2 \alpha}$. The contractile response was attenuated by chlorpheniramine alone and to a similar extent by combined treatment with chlorpheniramine and cimetidine, suggesting that $\mathrm{H}_{1^{-}}$ receptors are involved in the histamine-induced contraction. In contrast to a parellel shift of dosecontractile response curve for histamine to the right in dog cerebral arteries (present study), the contraction of isolated cat middle cerebral arteries is attenuated by chlorpheniramine in a non-competitive manner (Edvinsson \& Owman, 1975). The facts that cimetidine did not potentiate the histamine-induced contraction and in the presence of high concentrations of chlorpheniramine, no relaxation was induced by histamine suggest that the functional significance of $\mathrm{H}_{2}$-receptors in dog basilar and middle cerebral arteries is probably minimal. On the other hand, an $\mathrm{H}_{2}$-mediated vasodilatation has been demonstrated in small pial arteries and arterioles of anaesthetized cats (Wahl \& Kuschinsky, 1979). 


\section{References}

ANGUS, J.A. \& KORNER, P.I. (1977). Regional vascular resistance and heart rate responses mediated through $\mathrm{H}_{1}$ - and $\mathrm{H}_{2}$-histamine receptors in the unanaesthetised rabbit. Eur. J. Pharmac., 45, 45-53.

ASH, A.S.F. \& SCHILD, H.O. (1966). Receptors mediating some actions of histamine. Br. J. Pharmac. Chemother., 27, 427-439.

BLACK, J.W., DUNCAN, W.A.M., DURANT, C.J., GANELLIN, C.R. \& PARSONS, M.E. (1972). Definition and antagonism of histamine $\mathrm{H}_{2}$-receptors. Nature, 236, 385-390.

BLACK, J.W., OWEN, D.A.A. \& PARSONS, M.E. (1975). An analysis of the depressor responses to histamine in the cat and dog: involvement of both $\mathrm{H}_{1}$ - and $\mathrm{H}_{2}$-receptors. Br. J. Pharmac., 54, 319-324.

CORUZZI, G., BONGRANI, S. \& BERTACCINI, G. (1979). Histamine receptors in the heart and coronary vessels of rabbits. Pharmac. Res. Commun., 11, 517-528.

EDVINSSON, L. \& OWMAN, C. (1975). A pharmacologic comparison of histamine receptors in isolated extracranial and intracranial arteries in vitro. Neurology, 25, $271-276$.

ERCAN, Z.S. \& TÜRKER, R.K. (1975). Histamine receptors in the vasculature of the rabbit ear. NaunynSchmiedebergs Arch. Pharmac., 291, 23-29.

FLYNN, S.B. \& OWEN, D.A.A. (1975). Histamine receptors in peripheral vascular beds in the cat. Br. J. Pharmac., 55, $181-188$.

GUTH, P.H. \& SMITH, E. (1978a). Histamine receptors in the gastric microcirculation. Gut, 19, 1059-1063.

GUTH, P.H. \& SMITH, E. (1978b). Histamine receptors in mesenteric circulation of the cat and rat. Am.J. Physiol., 234, E370-E374.
HAGEN, M. \& PAEGELOW, I. (1980). Histamine $\mathbf{H}_{1}$ - and $\mathrm{H}_{2}$-receptors in coronary arteries of pigs. Agents \& Actions, 9, 253-256.

HARVEY, C.A., OWEN, D.A.A. \& SHAW, K.D. (1980). Evidence for both histamine $\mathrm{H}_{1}$ - and $\mathrm{H}_{2}$-receptors in the gastric vasculature of the cat. Br. J. Pharmac., 69, 21-27.

PAWLIK, W., TAGUE, L.L., TEPPERMAN, B.L., MILLAR, T.A. \& JACOBSON, E.D. (1977). Histamine $\mathrm{H}_{1^{-}}$and $\mathrm{H}_{2}$-receptor vasodilatation of canine intestinal circulation. Am. J. Physiol., 233, E219-E224.

TODA, N. (1974). The action of vasodilating drugs on isolated basilar, coronary and mesenteric arteries of the dog. J. Pharmac. exp. Ther., 191, 139-146.

TODA, N. (1977). Responses of isolated cerebral and peripheral arteries to vasoconstricting agents. In Neurogenic Control of Brain Circulation. ed. Owman, C. \& Edvinsson, L. pp. 207-217. Oxford: Pergamon Press.

TODA, N., HATANO, Y. \& HAYASHI, S. (1978). Modifications by streches of the mechanical response of isolated cerebral and extracerebral arteries to vasoactive agents. Pflügers Arch. Eur. J. Physiol., 374, 73-77.

TUCKER, A., WEIR, E.K., REEVES, J.T. \& GROVER, R.F. (1975). Histamine $\mathrm{H}_{1}$ - and $\mathrm{H}_{2}$-receptors in pulmonary and systemic vasculature of the dog. Am. J. Physiol., 229, $1008-1013$.

WAHL, M. \& KUSCHINSKY, W. (1979). The dilating effect of histamine on pial arteries of cats and its mediation by $\mathrm{H}_{2}$-receptors. Circulation Res., 44, 161-165.

(Received February 25, 1981. Revised April 22, 1981.) 